Onoja et al, Afr J Tradit Complement Altern Med., (2017) 14 (6): 56-63

https://doi.org/10.21010/ajtcam.v14i6.6

\title{
ANTIOXIDANT, ANTI-INFLAMMATORY AND ANTI-NOCICEPTIVE PROPERTIES OF HYDRO- METHANOL EXTRACT OF EREMOMASTAX SPECIOSA (HOCHST.) CUFOD LEAF
}

\author{
Samuel O. Onoja*1; Chinemerem Eke² Emmanuel Ejiofor $^{3}$; Kelechi G. Madubuike ${ }^{1}$; Maxwell I. \\ Ezeja $^{1}$; Yusuf N. Omeh ${ }^{2}$ and Aruh O. Anaga ${ }^{4}$
}

${ }^{1}$ Department of Veterinary Physiology, Pharmacology, Biochemistry and Animal Health and Production, Michael Okpara University of Agriculture, Umudike, Nigeria. ${ }^{2}$ Department of Biochemistry, Michael Okpara University of Agriculture, Umudike, Nigeria. ${ }^{3}$ Department of Biochemistry, Faculty of Sciences, Clifford University Owerrinta, Abia State. ${ }^{4}$ Department of Veterinary Physiology and Pharmacology, Faculty of Veterinary Medicine, University of Nigeria, Nsukka, Nigeria

*Corresponding Author Emails: samuelonoja19@yahoo.com; samonreal@yahoo.com; onoja.samuel@mouau.edu.ng

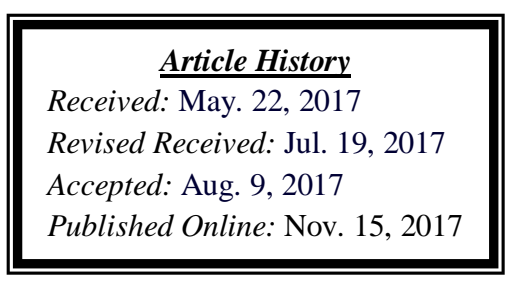

\section{Abstract}

Background: Eremomastax speciosa (Hochst.) Cufod is a perennial herb found in Africa along the rainforest zone and occurs as weed. It is cultivated in Cameroon and Akwa-Ibom in Nigeria due to its medicinal values. This study investigated the antioxidant, anti-inflammatory and antinociceptive properties of hydromethanol extract of Eremomastax speciosa (Hochst.) Cufod leaf in rat model.

Materials and Methods: The plant material was extracted using cold maceration method in $80 \%$ hydromethanol. The acute oral toxicity test was performed using Up and Down method with limit dose of $2000 \mathrm{mg} / \mathrm{kg}$. The in vitro antioxidant property was evaluated with 2,2-diphenyl-1-picrylhydrazyl and ferric reducing antioxidant power photometric assays. The anti-inflammatory potential was investigated in egg-albumin and carrageenan induced paw edema models while the antinociceptive activity was determined using acetic acid induced writhing reflex and tail immersion tests at the doses of 50, 100 and $200 \mathrm{mg} / \mathrm{kg}$. The negative control group (group A) received distilled water (vehicle) at $5 \mathrm{ml} / \mathrm{kg}$ while acetyl salicylic acid $(200 \mathrm{mg} / \mathrm{kg}$ ) was used as the reference drug for the anti-inflammatory models and acetic acid induced writhing reflex model while pentazocine $(5 \mathrm{mg} / \mathrm{kg})$ was used as the reference drug for tail immersion test.

Results: The $\mathrm{LD}_{50}$ of the extract was greater than $2000 \mathrm{mg} / \mathrm{kg}$. The extract ( 25 to $400 \mu \mathrm{g} / \mathrm{ml}$ ) demonstrated potent antioxidant activities in both the 2,2-diphenyl-1-picrylhydrazyl and ferric reducing antioxidant power assays. The $E$. speciosa extract caused significant $(\mathrm{P}<0.05)$ anti-inflammatory and antinociceptive activities in the extract treated groups when compared to rats that received distilled water. The optimal activities of the extract were produced at the dose of $100 \mathrm{mg} / \mathrm{kg}$.

Conclusion: The study supports the folkloric use of Eremomastax speciosa leaf in the management of pain and inflammatory conditions in traditional medicine.

Keywords: Acetic acid, anti-inflammatory, antinociceptive, antioxidant, carrageenan, Eremomastax speciosa.

\section{Introduction}

Eremomastax speciosa (Hochst.) Cufod commonly known as "edem iduodut" or "ndadad edem" by Ibibio people and "African blood tonic" in Cameroon belong to the family Acanthaceae (Iba et al., 2015). It is a perennial herb found in Africa along the rainforest zone and occurs as weed. It is cultivated in Cameroon and Akwa-Ibom in Nigeria due to its medicinal values (Oben et al., 2006). It is a polymorphous herb that grows up to $2 \mathrm{~m}$ high with remarkable quadrangular stem (Amang et al., 2014). The leaf (decoction or infusion or maceration) is used by the natives in the treatment of dysentery, anaemia, menstrual pain, fracture, hemorrhoids and urinary tract infection (Iba et al., 2015; Oben et al., 2006; Kuete et al., 2013). The aerial part of the plant has been reported in scientific literature to possess antianaemic, antiulcer, antisecretory, antimicrobial, antifungal and antidiarrheal activities (Amang et al., 2014; Iba et al., 2015; Oben et al., 2006; Okokon et al., 2007; Mouokeu et al., 2015; Tan et al., 1996). There was dearth of information on the anti-inflammatory and antinociceptive activities of E. speciosa, despite its use for this purpose in 
traditional medicine of various cultures. The main aim of the study was to investigate the antioxidant, antiinflammatory and antinociceptive activities of methanol extract of $E$. speciosa (Hochst.) Cufod leaf.

\section{Materials and Methods}

Harvest and identification plant sample

The leaves of E. speciosa (Hochst.) Cufod were harvested from uncultivated farmlands in June 2015 from Ikot-Ekwere Itam in Itu, Akwa-Ibom State Nigeria and identified by Mr. Okon Etefia. A voucher sample label MOUAU/VPP/2015/15 was deposited in the departmental herbarium for reference purposes.

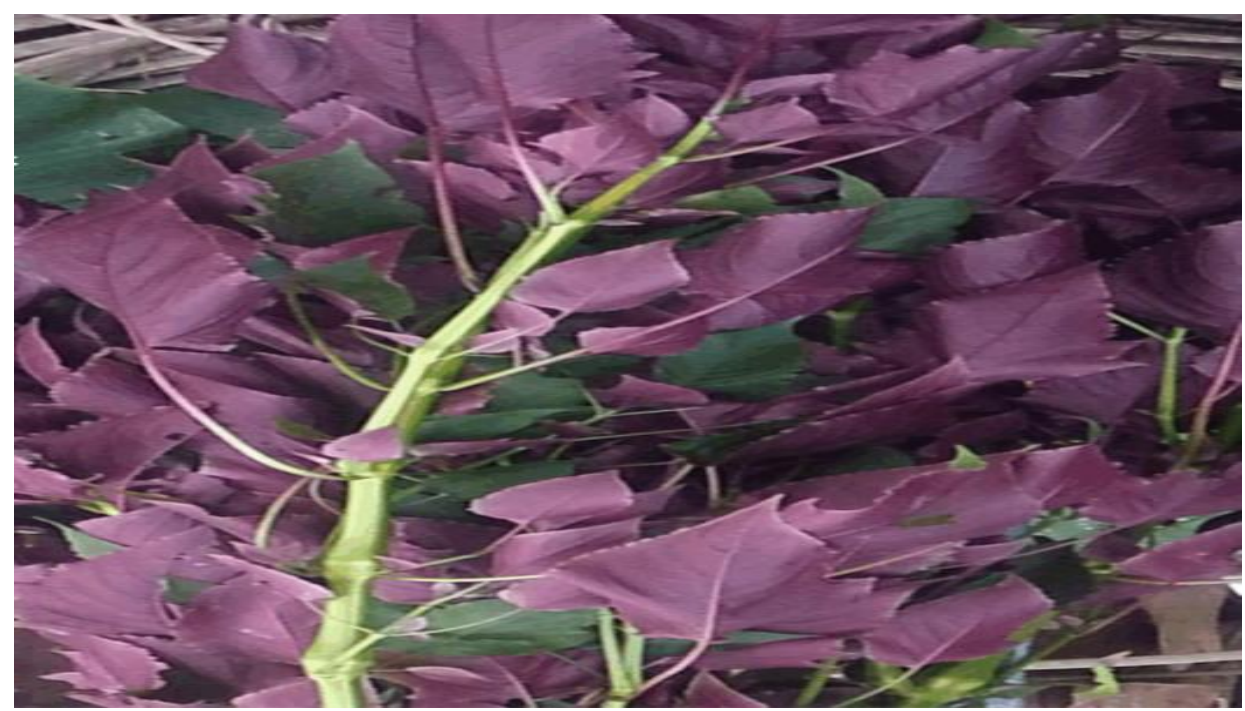

Figure 1: Photograph of Eremomastax speciosa (Hochst.) Cufod

\section{Preparation of $E$. speciosa extract}

The leaves of E. speciosa were air dried under shed and ground into coarse powder with manual milling machine (Corona, China). Two hundred grams $(200 \mathrm{~g})$ of the coarse powder of E. speciosa was soaked in $80 \%$ hydromethanol (Sigma Aldrich, USA) for $48 \mathrm{~h}$ ( 2 days) at room temperature with intermittent agitation ( $3 \mathrm{~h}$ interval) in a Winchester bottle and filtered with Whatman No. 1 filter papers. The filtrate was concentrated at $40^{\circ} \mathrm{C}$ in hot air oven and the extract was stored in a refrigerator at $4{ }^{\circ} \mathrm{C}$ as E. speciosa extract (ESE) (Onoja et al., 2016). The percentage yield was calculated as follow;

$\%$ yield $(w / w)=($ weight of extracted material $\div$ weight of plant material $) \times 100 / 1$

\section{Antioxidant study}

\section{2, 2-Diphenyl-1-picrylhydrazyl (DPPH) scavenging Assay}

The DPPH (Sigma Aldrich, USA) radical scavenging activity of ESE was determined as described by Ezeja et al. (2015) at 25, 50, 100, 200 and $400 \mu \mathrm{g} / \mathrm{ml}$ concentrations in triplicate and ascorbic acid was used as standard.

\section{Ferric reducing antioxidant power (FRAP)}

The FRAP of ESE was evaluated as described in Onoja et al. (2016). The FRAP of ESE at 25, 50, 100, 200 and $400 \mu \mathrm{g} / \mathrm{ml}$ concentrations was determined in triplicate.

\section{Experimental animals}

Total of 126 Wistar albino rats of either sexes weighing 90-105 g were employed in the study. The rats were kept in stainless steel cages at ambient temperature and natural light/darkness cycles. The rats were given clean tap water and fed ad libitum with commercial feed (Vital feed® Nigeria). The rats were managed in accordance with the recommendations of the guide for the care and use of laboratory animals (Ward and Elsea, 1997) and the experimental protocol was approved by the institution's ethical committee. 


\section{Oral acute toxicity test}

The Up and Down method of oral acute toxicity test was used to determine the $\mathrm{LD}_{50}(\mathrm{OECD}, 2008)$. Three rats received $2000 \mathrm{mg} / \mathrm{kg}$ of ESE while three other rats were given same volume of distilled water, orally by gastric gavage. The rats were monitored for $48 \mathrm{~h}$ for signs of toxicity and mortality.

\section{Anti-inflammatory study \\ Carrageenan - induced paw edema}

The modified carrageenan-induced paw edema model described by Ghante et al. (2014) was employed in the conduct of this experimental protocol. Briefly, 30 albino rats were randomly assigned to 5 groups $(A-E)(n=6)$. The rats in group A received $5 \mathrm{ml} / \mathrm{kg}$ of distilled water (DW) (negative (-ve) control), group B rats received $200 \mathrm{mg} / \mathrm{kg}$ of acetylsalicylic acid (ASA) (positive (+ve) control) while rats in groups C, D and E received 50, 100 and $200 \mathrm{mg} / \mathrm{kg}$ of ESE, respectively. Sixty minutes post administration of ASA and ESE, $0.1 \mathrm{ml}$ of carrageenan (Sigma Aldrich, USA) ( $0.5 \%$ in normal saline) was injected into the sub-plantar area of the right hind paw. The paw volumes of the rats were estimated through displacement of water and measured with electronic balance of $0.01 \mathrm{~g}$ accuracy. The left paw volumes served as control $\left(\mathrm{V}_{\mathrm{o}}\right)$. The volume $\left(\mathrm{V}_{\mathrm{t}}\right)$ of the right hind paw was measured at 1,2 and $3 \mathrm{~h}$ post carrageenan administration. The change in volume due to carrageenan-induced paw swelling was calculated as $\left(V_{t}-V_{o}\right)$ while the percent inhibition was calculated using the formula below: Percent inhibition $=\frac{Y-Z}{Y} \times \frac{100}{1}$

Where $\mathrm{Y}$ is the change in paw volume $\left(\mathrm{V}_{\mathrm{t}}-\mathrm{V}_{\mathrm{o}}\right)$ of distilled water treated group and $\mathrm{Z}$ is the change in paw volume $\left(\mathrm{V}_{\mathrm{t}}\right.$ $-\mathrm{V}_{\mathrm{o}}$ ) of each test group.

\section{Egg-albumin-induced paw edema}

The method of Ghule et al. (2006) was adopted for this experiment. Thirty albino rats fasted overnight (16 h) were randomly assigned into 5 groups $(\mathrm{A}-\mathrm{E})(\mathrm{n}=6)$. Group A rats received $5 \mathrm{ml} / \mathrm{kg}$ of DW (-ve control), rats in group B were treated with $200 \mathrm{mg} / \mathrm{kg}$ of ASA (+ve control) and group C, D and E were treated with 50, $100 \mathrm{and} 200 \mathrm{mg} / \mathrm{kg}$ of ESE, respectively. Thirty minutes after treatment; paw edema was induced by injecting $0.05 \mathrm{ml}$ of raw egg-albumin into the sub-plantar area of the hind right paw. The left paw volumes served as control. The right paw volume was determined at 1, 2 and $3 \mathrm{~h}$ post treatment. Measurement and percent inhibition were as stated above.

\section{Antinociceptive study}

\section{Acetic acid-induced abdominal writhing reflex in rats}

The Effects of ESE on acetic acid induced abdominal writhing reflex was conducted according to the method of Zakaria et al. (2001). Briefly, 30 rats were assigned to five groups (A-E) $(n=6)$. Group A rats served as -ve control and received DW $(5 \mathrm{ml} / \mathrm{kg}$ ) while rats in group B served as +ve control and received ASA (200 mg/kg). Groups C-E rats received 100, 200 and $400 \mathrm{mg} / \mathrm{kg}$ extract, respectively. The treatments were administered orally. Forty five (45) min post treatment, the rats received $10 \mathrm{ml} / \mathrm{kg}$ of $0.7 \%$ acetic acid intraperitoneally (i.p). The abdominal stretches produced in each rat were counted for $30 \mathrm{~min}$. Percent activity was calculated using the formula below: $\frac{(X-Y)}{X} \times \frac{100}{1}$ Where $\mathrm{X}$ is the mean writhing reflex of distilled water treated group and $\mathrm{Y}$ is the mean writhing reflex of each test groups.

\section{Tail immersion test}

The experiment was conducted as described by Alam et al. (2009). Thirty rats were randomly assigned to 5 groups (A-E) $(\mathrm{n}=6)$. Group A received DW $5 \mathrm{ml} / \mathrm{kg}$ orally (-ve control), Group B received pentazocine $5 \mathrm{mg} / \mathrm{kg}$ (i.p) (-ve control), while Groups C-E received extract 100, 200 and $400 \mathrm{mg} / \mathrm{kg}$ orally, respectively. One hour treatment, about $3 \mathrm{~cm}$ of the tail of each rat was dipped into a water bath maintained at a temperature of $55 \pm 1^{\circ} \mathrm{C}$. The pain reaction time (PRT) each rat was recorded. Percent antinociception was calculated using the formula below: percent antinociception $=\left\{\frac{(\mathrm{Tt}-\mathrm{To})}{\mathrm{To}}\right\} \times \frac{100}{1}$

Where $T_{o}$ is the mean PRT of distilled water treated group and $T_{t}$ is the mean PRT of each test groups.

\section{Data analysis}

Data were presented as mean \pm standard error of mean (SEM) and analyzed with statistical package of social science (SPSS) version 20 using one way analysis of variance (ANOVA). Least Significant Difference (LSD) was used to separate mean difference and significance was accepted at the level of $\mathrm{p}<0.05$. 


\section{Results}

In vitro antioxidant activities of ESE

The DPPH radical scavenging activity of ESE

The ESE caused a significant $(\mathrm{p}<0.05)$ concentration dependent increase in the antioxidant activity. The optimal effect was produced at $400 \mu \mathrm{g} / \mathrm{ml}$ concentration. The inhibition concentration $50 \%\left(\mathrm{IC}_{50}\right)$ of the extract is approximately $200 \mu \mathrm{g} / \mathrm{ml}$ concentration. The antioxidant activities of ESE was significantly $(\mathrm{p}<0.05)$ lower than that of ascorbic acid (Figure 2).

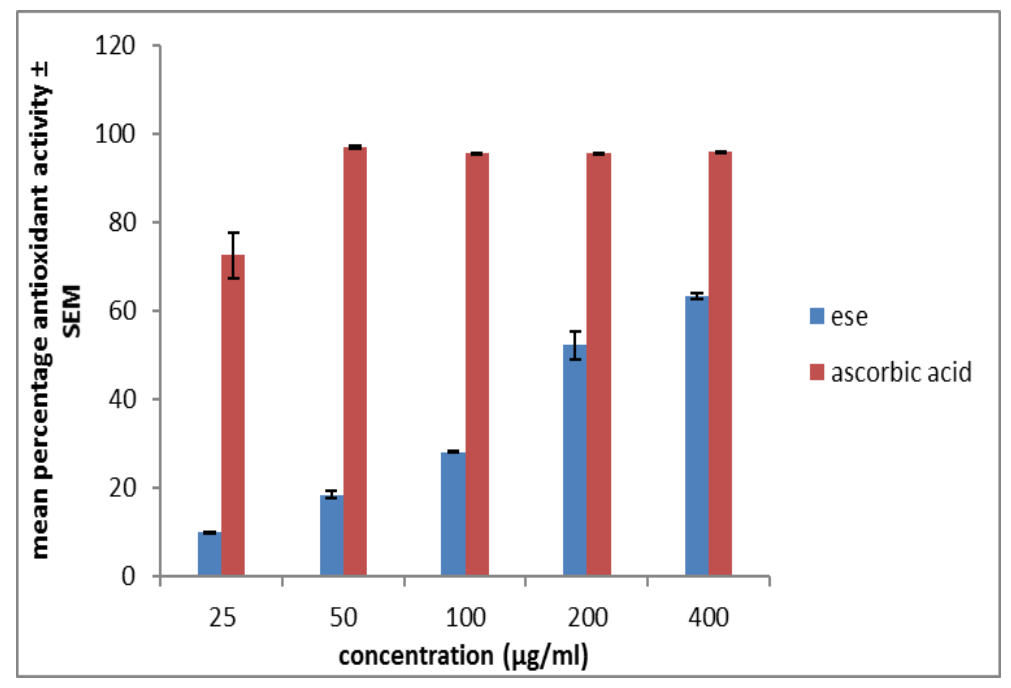

Figure 2: The 2,2-diphenyl-1-picrylhydrazyl radical scavenging activities of ESE Legend: $\mathrm{ESE}=$ Eremomastax speciosa extract; $\mathrm{SEM}=$ standard error of mean.

\section{FRAP assay}

The ESE caused concentration dependent increase in antioxidant power. The antioxidant power of the extract is significantly $(\mathrm{p}<0.05)$ lower than ascorbic acid (Figure 3).

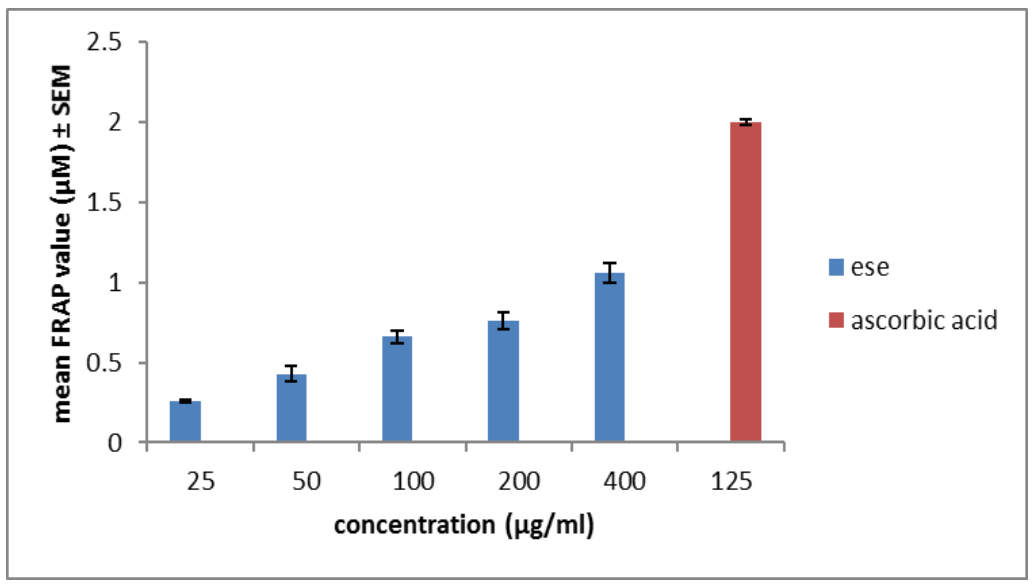

Figure 3: Ferric reducing antioxidant power of ESE.

Legend: ESE = Eremomastax speciosa extract; FRAP = ferric reducing antioxidant power; $\mathrm{SEM}=$ standard error of mean.

\section{Oral acute toxicity test}

Eremomastax speciosa (ESE) did not cause observable clinical signs of toxicity and mortality in treated rats at dose of $2000 \mathrm{mg} / \mathrm{kg}$. The $\mathrm{LD}_{50}$ of ESE is greater than $2000 \mathrm{mg} / \mathrm{kg}$. 


\section{Carrageenan induced paw edema}

The ASA and ESE treatment caused reduced paw volume in the treated rats when compared to DW treated group. The extract $(100 \mathrm{mg} / \mathrm{kg})$ significantly $(\mathrm{P}<0.05)$ reduced the paw volumes of the treated rats at 1,2 and $3 \mathrm{~h}$ post treatment when compared DW treated rats. (Table 1).

Table 1: Effect of ESE on carrageenan induced paw edema

\begin{tabular}{llll}
\hline \multirow{2}{*}{ Treatment } & \multicolumn{3}{l}{ Mean increase in paw volume $(\mathrm{ml}) \pm$ SEM $(\%$ inhibition $)$} \\
\hline DW $5 \mathrm{mg} / \mathrm{kg}$ & $1 \mathrm{~h}$ & $2 \mathrm{~h}$ & $3 \mathrm{~h}$ \\
ASA $200 \mathrm{mg} / \mathrm{kg}$ & $0.50 \pm 0.03(-)$ & $0.66 \pm 0.03(-)$ & $0.68 \pm 0.05(-)$ \\
ESE $50 \mathrm{mg} / \mathrm{kg}$ & $0.47 \pm 0.06(6)$ & $0.61 \pm 0.05(8)$ & $0.65 \pm 0.04(4)$ \\
ESE $100 \mathrm{mg} / \mathrm{kg}$ & $0.49 \pm 0.07(2)$ & $0.65 \pm 0.04(3)$ & $0.63 \pm 0.04(7)$ \\
ESE $200 \mathrm{mg} / \mathrm{kg}$ & $0.38 \pm 0.05^{*}(24)$ & $0.49 \pm 0.04 *(26)$ & $0.58 \pm 0.03 *(15)$ \\
\hline
\end{tabular}

${ }^{*} \mathrm{p}<0.05$ when compared to DW treated group. $\mathrm{SEM}=$ standard error of mean, DW = water distilled, ESE = Eremomastax speciosa extract; ASA = acetyl salicylic acid; $\mathrm{h}=$ hour; $\%=$ percentage; $\mathrm{ml}=$ mililitre .

\section{Egg albumin-induced paw edema}

The ESE significantly $(\mathrm{p}<0.05)$ decreased the paw volume of the treated rats in a non dose-dependent manner when compared to the DW treated rats. At $3 \mathrm{~h}$ post treatment, the paw volume of the negative control was $0.91 \pm 0.04$ $\mathrm{ml}$ while the paw volumes of ASA and $\operatorname{ESE}(50,100$ and $200 \mathrm{mg} / \mathrm{kg}$ ) treated rat groups were $0.57 \pm 0.04,0.57 \pm 0.03$, $0.59 \pm 0.05$ and $0.61 \pm 0.06$, respectively (Table 2 )

\section{Acetic acid-induced writhing reflex}

Acetyl salicylic acid and ESE $(100$ and $200 \mathrm{mg} / \mathrm{kg})$ caused significant $(\mathrm{P}<0.05)$ reduction in writhing reflex in the treated rats when compared to DW treated rats (Table 3 ).

Table 2: Effect of ESE on egg albumin-induced paw edema

\begin{tabular}{llll}
\hline & \multicolumn{3}{l}{ Mean increase in paw volume $(\mathrm{ml}) \pm$ SEM $(\%$ inhibition) } \\
Group $(\mathrm{n}=6)$ & $1 \mathrm{~h}$ & $2 \mathrm{~h}$ & $3 \mathrm{~h}$ \\
\hline DW $5 \mathrm{mg} / \mathrm{kg}$ & $1.16 \pm 0.08(-)$ & $0.94 \pm 0.05(-)$ & $0.91 \pm 0.04(-)$ \\
ASA $200 \mathrm{mg} / \mathrm{kg}$ & $0.87 \pm 0.03^{*}(25)$ & $0.64 \pm 0.01^{*}(32)$ & $0.57 \pm 0.04 *(37)$ \\
ESE $50 \mathrm{mg} / \mathrm{kg}$ & $0.88 \pm 0.05^{*}(24)$ & $0.68 \pm 0.07 *(28)$ & $0.57 \pm 0.03^{*}(37)$ \\
ESE $100 \mathrm{mg} / \mathrm{kg}$ & $0.95 \pm 0.05^{*}(18)$ & $0.80 \pm 0.04^{*}(15)$ & $0.59 \pm 0.05^{*}(35)$ \\
ESE $200 \mathrm{mg} / \mathrm{kg}$ & $1.02 \pm 0.08(12)$ & $0.78 \pm 0.08^{*}(17)$ & $0.61 \pm 0.06^{*}(33)$ \\
\hline
\end{tabular}

$* \mathrm{p}<0.05$ when compared to DW treated group. SEM $=$ standard error of mean, DW $=$ water distilled, ESE = Eremomastax speciosa extract; ASA = acetyl salicylic acid; $\mathrm{h}=$ hour; $\%=$ percentage; $\mathrm{ml}=$ mililitre .

Table 3: Effect of ESE on acetic acid-induced writhing reflex

\begin{tabular}{lll}
\hline Group $(\mathrm{n}=6)$ & Mean writhing reflex \pm SEM & \% inhibition \\
\hline DW $5 \mathrm{mg} / \mathrm{kg}$ & $32.20 \pm 0.73$ & - \\
ASA $200 \mathrm{mg} / \mathrm{kg}$ & $22.30 \pm 0.91 * * *$ & 30.75 \\
ESE $50 \mathrm{mg} / \mathrm{kg}$ & $30.00 \pm 0.71$ & 6.83 \\
ESE $100 \mathrm{mg} / \mathrm{kg}$ & $23.20 \pm 1.07 * * *$ & 27.95 \\
ESE $200 \mathrm{mg} / \mathrm{kg}$ & $27.20 \pm 1.59^{* * *}$ & 15.53 \\
\hline
\end{tabular}

$* \mathrm{P}<0.05 ; * * \mathrm{P}<0.01 ; * * * \mathrm{P}<0.001$ when compared to DW treated group. SEM = standard error of mean, DW = water distilled, ESE = Eremomastax speciosa extract; ASA = acetyl salicylic acid; $\%=$ percentage .

\section{Tail immersion test}

Pentazocine $(5 \mathrm{mg} / \mathrm{kg})$ and ESE $(50,100$ and $200 \mathrm{mg} / \mathrm{kg})$ caused prolonged $(\mathrm{P}<0.05)$ PRT in treated rats when compared to the DW treated rats. Pentazocine and ESE $(100 \mathrm{mg} / \mathrm{kg})$ caused significant $(\mathrm{P}<0.05)$ increase in PRT $(3.32$ \pm 0.42 and $3.08 \pm 0.33$ respectively) of the treated groups when compared to DW treated group (2.29 \pm 0.17$)$. There was no significant $(\mathrm{p}<0.05)$ difference between pentazocine and ESE, $100 \mathrm{mg} / \mathrm{kg}$ treated groups $($ Table 4). 
Table 4: Effect of ESE in tail immersion test

\begin{tabular}{lll}
\hline Group $(\mathrm{n}=6)$ & PRT $(\mathrm{sec}) \pm$ SEM & \% increase in PRT \\
\hline DW $10 \mathrm{mg} / \mathrm{kg}$ & $2.29 \pm 0.17$ & - \\
Pentazocine $5 \mathrm{mg} / \mathrm{kg}$ & $3.32 \pm 0.42^{*}$ & 44.98 \\
ESE $50 \mathrm{mg} / \mathrm{kg}$ & $2.58 \pm 0.30$ & 12.66 \\
ESE $100 \mathrm{mg} / \mathrm{kg}$ & $3.08 \pm 0.33^{*}$ & 34.50 \\
ESE $200 \mathrm{mg} / \mathrm{kg}$ & $2.50 \pm 0.28$ & 9.17 \\
\hline
\end{tabular}

$* p<0.05$ when compared to DW treated group. SEM = standard error of mean; DW = water distilled; ESE = Eremomastax speciosa extract; ASA = acetyl salicylic acid; PRT = Pain reaction time; $\mathrm{h}=$ hour; $\%=$ percentage; Sec $=$ second.

\section{Discussion}

Oral acute toxicity of the extract of Eremomastax speciosa (ESE) did not cause any observable clinical signs of toxicity and mortality in treated rats at dose of $2000 \mathrm{mg} / \mathrm{kg}$. This indicates that the oral $\mathrm{LD}_{50}$ of the ESE was greater than $2000 \mathrm{mg} / \mathrm{kg}$.

The extract demonstrated good anti-inflammatory, antinociceptive and antioxidant properties which may be attributed to the phytoconstituents. Ndam et al. (2014) reported that E. speciosa contain flavonoids, saponins and terpenes. The anti-inflammatory, antioxidant and antinociceptive properties of these phytoconstituents have been documented (Aladedunye et al., 2008; Otimenyin et al., 2008).

The mechanism of the anti-inflammatory and antinociceptive effect of $E$. speciosa was not established, but could be through inhibition of cyclooxygenase activity. Cyclooxygenase catalyze the biosynthesis of prostaglandins (potent inflammatory mediator) from arachidonic acid (Alam et al., 2009). Most non-steroidal anti-inflammatory drugs act via the inhibition of cyclooxygenase (Rang et al., 2007; Balakumar et al., 2010).

Egg-albumin, carrageenan and acetic acid induces inflammation and pain sensation through stimulation of inflammatory mediators (cytokine, histamine, prostaglandins, polymorphonuclear leucocytes and thromboxane) in the tissue and increased vascular permeability (Marsik et al., 2005; Silva et al., 2014). The extract might have acted through the inhibition of synthesis and migration of inflammatory mediator to the site of inflammation. Hassan et al. (2016) reported the anti-inflammatory properties of Cajanus cajan extract and proposed inhibition of inflammatory mediators migration as its mechanism of action.

Also, the anti-inflammatory effects of E. speciosa may be linked to antioxidant activity. Silva et al. (2014) associated the anti-inflammatory effects of phytol, a diterpene to its antioxidant property. Inflammatory reaction is usually associated with reactive oxygen species which are mopped up by antioxidant. Also, antioxidant effects of $E$. speciosa will ameliorate oxidative stress which accompanies inflammatory conditions (Casado et al., 2010).

The extract prolonged the pain reaction time (PRT) of the treated rats which suggests that it may be a centrally acting analgesic agent. The increase in PRT may be due to elevation of pain threshold in the hypothalamus (Singh et al., 2016). The decrease in writhing reflex in the extract treated group suggests that E. speciosa has peripheral analgesic effects (Silva et al., 2003).

The anti-inflammatory and antinociceptive activities of E. speciosa leaf are comparable to the effects produced by Ormosia coccinea and Phyllanthus maderaspatensis (Adnan et al., 2014; Wagle et al., 2016). The little difference in activities may be linked to variation in phytochemical constituents which depend on the stage of vegetative growth, part of the plant collected, soil type and other climatic factors (Sofowora, 2008).

In conclusion, the methanol extract of E. speciosa demonstrated good anti-inflammatory, antinociceptive and antioxidant properties. The results support the folkloric use of Eremomastax speciosa leaf in the management of pain and inflammatory conditions. The plant may provide source of novel anti-inflammatory and antinociceptive drug(s). Further studies aimed at isolation and characterizations of active principles are ongoing in our laboratory.

\section{Acknowledgement}

The authors are grateful to Mr. Okon Etefia, a Pharmacognocist in the Department of Pharmacology/Natural Medicine, University of Uyo, Akwa Ibom state, Nigeria for identification of the plant sample.

Conflict of interest: The authors declare no conflict of interest. 


\section{Reference}

1. Adnan, M.S.A., Al-Amin, M.M., Uddin, M.M.N., Shohel,M., Bhattacharjee, R., Hannan J.M.A., Das, B.K. (2014). Analgesic, anti-inflammatory, and antipyretic effects of Ixora coccinea. J. Basic Clin. Physiol. Pharmacol. 25(4): 423428.

2. Aladedunye, F.A., Okorie, D.A. and Ighodaro, O.M. (2008). Anti-inflammatory and antioxidant activities and constituents of Platostoma africanum P. Beauv. Nat. Prod. Res. 22(12): 1067-1073

3. Alam, M.A., Subhan, N., Awal, M.A., Alam, M.S., Sarder, M., Nahar, L., Sarker, S.D. (2009). Antinociceptive and anti-inflammatory properties of Ruellia tuberose. Pharm. Biol. 47(3): 209-214

4. Amang, A.P., Tan, P.V., Ernestine, N. and Barthélemy, N. (2014). Antisecretory action of the extract of the aerial parts of Eremomastax speciosa (Acanthaceae) occurs through antihistaminic and anticholinergic pathways. Adv. Pharmacol. Sci. Article ID 323470, http://dx.doi.org/10.1155/2014/323470

5. Balakumar, C., Lamba, P., Kishore, D.P., Narayana, B.L., Rao, K.V., Rajwinder, K., Rao, A.R., Shireesha, B and Narsaiah, B. (2010). Synthesis, anti-inflammatory evaluation and docking studies of some new fluorinated fused quinazolines. Eur. J. Med. Chem. 45(11): 4904 - 4913.

6. Casado, R., Landa, A., Calvo, J.J., Terencio, M.C. and Calvo, M.I. (2010). Anti-inflammatory and antioxidant activities of Jungia paniculata. Pharm. Biol. 48(8): 897-905.

7. Ezeja, M.I., Omeh, Y.N., Onoja, S.O. and Ukaonu, I.H. (2015). Anti-inflammatory and antioxidant activities of the methanolic leaf extract of Cissus aralioides. Am. J. Pharmacol. Sci. 3(1): 1-6.

8. Ghante, M.H., Bhusari, K.P., Duragkar, N.J. and Ghiware, N.B. (2014). Pharmacological evaluation for anti-asthmatic and anti-inflammatory potential of Woodfordia fruticosa flower extracts. Pharm. Biol. 52(7): 804-813.

9. Ghule, B.V., Ghante, M.H., Upaganlawar, A.B. and Yeole, P.G. (2006). Analgesic and anti-inflammatory activities of Lagenaria siceraria Stand. fruit juice extract in rats and mice. Pharmacogn. Mag. 2(8): 232-236.

10. Hassan, E.M., Matloub, A.A., Aboutabl, M.E., Ibrahim, N.A. and Mohamed, S.M. (2016). Assessment of antiinflammatory, antinociceptive, immunomodulatory, and antioxidant activities of Cajanus cajan L. seeds cultivated in Egypt and its phytochemical composition. Pharm. Biol. 54(8): 1380-1391.

11. Iba, I.U., Etuk, E.U., Akpanabiatu, M.I., Item, E. and Ekong, I.N. (2015). Anti-anaemic and nephrotoxic effect of ethanolic extract Eremomastax speciosa. MRJMMS. 3(1): 10 - 12.

12. Kuete, V., Voukeng, I.K., Tsobou, R., Mbaveng, A.T., Wiench, B., Beng, V.P. and Efferth, T. (2013). Cytotoxicity of Elaoephorbia drupifera and other Cameroonian medicinal plants against drug sensitive and multidrug resistant cancer cells. BMC Complement. Altern. Med. 13: 250. http://www.biomedcentral.com/1472-6882/13/250

13. Marsik, P., Kokoska, L., Landa, P., Nepovim, A., Soudek, P. and Vanek, T. (2005). In vitro inhibitory effects of thymol and quinones of Nigella sativa seeds on cyclooxygenase-1- and -2-catalyzed prostaglandin E2 biosyntheses. Planta Med. 71(8):739-742.

14. Mouokeu, R.S., Kuenemo, S.M., Njateng, G.S.S., Kamtchueng, M.O., Fonkeng, L.S. and Kuiate, J.R. (2015). Activity of methanol/methylene extract mixtures from Monodora myristica (Gaertn), Xylopia aethiopica and Eremomastax speciosa (Hochst.) against Candida albicans. Pharmacologia. 6(8): 430-437.

15. Ndam, L.M., Mih, A.M., Fongod, A.G.N., Tening, A.S., Tonjock, R.K., Enang, J.E., and Fuji, Y. (2014). Phytochemical screening of the bioactive compounds in twenty (20) Cameroonian medicinal plants. Int. J. Curr. Microbiol. App. Sci. 3(12): 768-778.

16. Oben, J.E., Assi, S.E., Agbor, G.A. and Musoro, D.F. (2006). Effect of Eremomastax speciosa on experimantal diarrhoea. Afr. J. Trad. Complement. Altern. Med. 3(1): 95-100.

17. Okokon, J.E., Antia, B.S., Udoh, A.E. and Akpan, M.M. (2007). Antianaemic and antimicrobial activity of Eremomastax speciosa. J. Pharmacol. Toxicol. 2(2): 196-199.

18. Onoja, S.O., Ezeja, M.I., Omeh, Y.N. and Onwukwe, B.C. (2016). Antioxidant, anti-inflammatory and antinociceptive activities of methanolic extract of Justicia secunda Vahl leaf. Alex. J. Med. http://dx.doi.org/10.1016/j.ajme.2016.06.001

19. Organization for Economic Cooperation and Development. (2008). OECD guidelines for the testing of chemicals, acute oral toxicity - up-and down procedure. No. 425. Paris: Organization for Economic Cooperation and Development. [Online] Available

from: http://www.oecdilibrary.org/docserver/download/9742501e.pdf?expires=1437730561\&id=id\&accname=guest\&checks um=0B6C86B8F1B2E751997E5F54CFDF8F5E > [accessed on 5th May, 2015].

20. Otimenyin, S.O., Uguru, M.O. and Auta, A. (2008). Anti-Inflammatory and Analgesic Activities of Cassia goratensis and Sacrocephalus esculentus Extracts. J. Herbs Spices Med. Plants. 13(2): 59-67.

21. Rang, H.P., Dale, M.M., Ritter, J.M. and Moore, R.K. (2007). Pharmacology 6th edition, Edinburgh: Churchill livingstone.

22. Silva, J., Abebe, W., Sousa, S.M., Duarte, V.G., Machado, M.I. and Matos, F.J. (2003). Analgesic and antiinflammatory effects of essential oils of Eucalyptus. J. Ethnopharmacol. 89(2-3): 277-283.

23. Silva, R.O., Sousa, F.B., Damasceno, S.R., Carvalho, N.S., Silva, V.G., Oliveira, F.R., Sousa, D.P., Aragão, K.S., Barbosa, A.L., Freitas, R.M. and Medeiros, J.V.R. (2014). Phytol, a diterpene alcohol, inhibits the inflammatory response by reducing cytokine production and oxidative stress. Fundam. Clin. Pharmacol. 28(4): 455-464. 
24. Singh, P.A., Brindavanam, N.B., Kimothi, G.P. and Aeri, V. (2016). Evaluation of in vivo anti-inflammatory and analgesic activity of Dillenia indica f. elongata (Miq.) Miq. and Shorea robusta stem bark extracts. Asian Pac. J. Trop. Dis. 6(1): 75-81.

25. Sofowora, E.A. (2008). Medicinal Plants and Traditional Medicine in Africa, 3rd ed. Spectrum books Ltd, Ibadan, Nigeria.

26. Tan, P.V., Nditafon, N.G., Yewah, M.P., Dimo, T. and Ayafor, F.J. (1996). Eremomastax speciosa: effects of leaf aqueous extract on ulcer formation and gastric secretion in rats. J. Ethnopharmacol. 54(2-3): 139-142.

27. Wagle, N., Nagarjuna, S., Sharma, H., Dangi, N.B., Sapkota, H.P., Naik, B.S. and Padhaya, R.R. (2016). Evaluation of antinociceptive and anti-inflammatory activity of phytosterol present in chloroform extract of Phyllanthus maderaspatensis. Indian J. Physiol. Pharmacol. 60(1): 90-95.

28. Ward, J.W. and Elsea, J.R. (1997). Animal case and use in drug fate and metabolism. In: Edward RG, Jean LH, editors. Methods and techniques. 1st ed. New York: Markel Dekker.

29. Zakaria, M.N., Islam, M.W., Radhakrishnan, R., Chen, H.B., Kamil, M., Al-Gifri, A.N., et al. (2001). Antinociceptive and antiinflammatory properties of Caralluma arabi. J. Ethnopharmacol. 76(2): 155-158. 